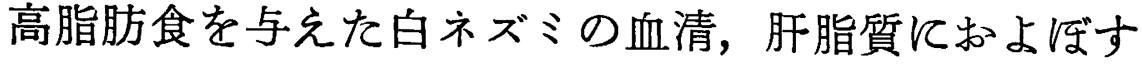 糖質と脂質の組合せの影響
}

\author{
小山恵子*, 鈴木敏 巳*, 中村 隆*, 铇田克彦** \\ * 秋田県立脳血管研究所内科 $* *$ 東北大学医学部第一内科
}

\section{Influence of Dietary Carbohydrate-Fat Combination on the Serum and Liver Lipid in Rats Fed High Fat Diet.}

\author{
Keiko Oyama*, Toshimi Suzuki*, Takashi Nakamura* \\ and Katsuhiko Tokita** \\ * Research Institute of Brain and Blood Vessels, Akita \\ ** First Dept. of Internal Medicine, Tohoku Univ. School of Medicine, Sendai
}

J. Jap. Soc. Food and Nutr., 25 (8), 615 620 (1972)

\begin{abstract}
Wister strain male rats were fed on cholesterol and thiouracil containing high fat diet for 20 weeks to examine the influence of dietary carbohydrate-fat combination on serum and liver lipid. Serum triglyceride, total cholesterol and phospholipid concentrations were studied. Total lipid and total cholesterol in the liver also measured. The dietary carbohydrate source was sucrose or rice starch and the dietary fat was butter or soy bean oil. In total, four kinds of dietary combinations were employed.

Among the rats fed soy bean oil, higher serum triglyceride level was shown by sucrose group rather than by rice starch group. But the reverse was fact on the rats fed butter as dietary fat source.

No difference was revealed in the serum cholesterol level between sucrose and rice starch group, both fed soy bean oil as dietary fat source.

Among the rats fed butter, higher serum cholesterol level was shown by sucrose group in 5 weeks after beginning of the experiment rather than by rice starch group, while opposite result was shown after that.

Serum phospholipid was higher on the sucrose group than the rice starch group, fed either soy bean oil or butter.

Total lipid and total cholesterol contents in the liver showed no noteworthy difference between sucrose and rice starch groups. This result was obtained both from rats fed soy bean oil and butter all the same.

To study the hyperlipidemia introduced by high fat diet, source of carbohydrate might be stressed, and moreover, fat and carbohydrate combination should play a great role for it.
\end{abstract}

(Received June 20, 1972)

動脈硬化の発生就よび進展と食䭒因子との関連につい ては種々の研究がなされている。その中で，撕取される 脂質のみならす糖質も動脈硬化と密接な関係のあること が, 疫学的および実験的に主張されている。なかです果 糖または蔗糖は,グルコース,でん粉にくらべて血中脂質 量を高める1) と)といわれ，またYudkin らは疫学的に心
筋硬塞と蔗煻の過食との関係を強調している4) -6)。

一方, 1955 年から 1957 年にかけて7) -10), 食䬲脂肪 と血中脂質の関連についても研究がなされ，血清コレス テロールは動物脂により上昇し，植物脂により低下する ことがいわれた。脂質の種類と動脈硬化についてる, 飽 和脂肪と不飽和脂肪による plaque, 血栓形成, 動脈硬 
化発生などの差をみている ${ }^{11)} 。$

ところが蔗糖とでん粉の体内脂質代謝に及ぼす影響を みるとき，組み合わされる脂質の質によってまったく違 った方向をたどるという報告もある(12)13)。以上のことか ら，食飰の影響をみる場合に組合せが大事であると考え て, 著者らは糖質として米でん粉, 蕉糖を使用し，これ に大豆油, バターを組み合わせ，高脂肪食の際の影響を 検討した。ラットに奏験的動脈硬化症を作製するのは一 般に困難とされている。

本実験では，高脂肪，コレステロール食にチオウラシ ル，コール酸を併用することにより plaque を作製でき ると報告している Gresham ${ }^{11)}$ らの方法を用いたが，高 脂血症と動脈硬化症の発症が相関すると一般にいわれて いることから，血液および肝脂質を中心に検討した。

\section{実 験 方 法}

\section{1. 実験動物および飼料}

ウイスター系白ネズミ雄, 体重 $150 \mathrm{~g}$ 前後のるのを各 群 24 匹用い, Table 1 に示す米でん粉（以下 Table, 図中で RS と略す）または鷹糖（S）およびバター（B） または大豆油（SBO）の組合せによる計 4 種類の実験食 で，20週間自由食で飼育した。Gresham の動脈硬化実 験では脂質を $40 \%$ にしているが，予備実験において多 数死亡したので本実験では脂質を 30\% に減らした。実 験期間中， 5，10，15，20 週目で絶食 12〜18 時間後, エーテル麻酔下で屠殺し実験に供した。

2. 血圧測定

血圧の測定は plethysmographic tail method ${ }^{15)}$ によ

Table 1. Experimental diet composition. (\%)

\begin{tabular}{|c|c|c|c|c|}
\hline Groups & $\begin{array}{c}\mathrm{I} \\
\mathrm{RS}+\mathrm{SBO}\end{array}$ & $\stackrel{\mathrm{II}}{\mathrm{S}+\mathrm{SBO}}$ & $\begin{array}{c}\text { III } \\
\mathrm{RS}+\mathrm{B}\end{array}$ & $\begin{array}{c}N \\
S+B\end{array}$ \\
\hline Casein & 20 & 20 & 20 & 20 \\
\hline Rice starch* & 37 & - & 37 & - \\
\hline Sucrose & - & 37 & - & 37 \\
\hline Soy bean oil & 30 & 30 & - & - \\
\hline Butter & - & - & 30 & 30 \\
\hline Cholesterol & 5 & 5 & 5 & 5 \\
\hline Cholic acid & 2 & 2 & 2 & 2 \\
\hline Thiouracil & 0.3 & 0.3 & 0.3 & 0.3 \\
\hline Salt mixture** & 4 & 4 & 4 & 4 \\
\hline Vitamin mixture** & 1.5 & 1. 5 & 1.5 & 1.5 \\
\hline Choline chloride & 0.2 & 0.2 & 0.2 & 0.2 \\
\hline
\end{tabular}

to each $100 \mathrm{~g}$ of diet the following vitamins were added

$\begin{array}{lr}\text { vitamin A } & 200 \mathrm{I} . \mathrm{U} . \\ \text { vitamin D } & 40 \mathrm{I} . \mathrm{U} . \\ \alpha \text {-Toc. acetate } & 30 \mathrm{mg}\end{array}$

* made by treatment with sodium hydroxide

** Tanabe Amino Acid Research Foundation
り, 夏目製作所のプレスチモ式ラット血珐計, KN 208 II 型を使用した。

\section{3. 血清脂蜇の測定}

血清コレステロール，中性脂肪，リン脂質は和光純薬 工業株式会社, 臨床検査用キットを用いて測定した。

\section{4. 肝脂翼の測定}

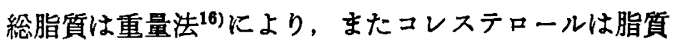
抽出後，上述のキットを用い測定した。

\section{5. 血清脂筫脂肪酸組成の分析}

脂質の抽出は Folch ${ }^{17)}$ の方法により,メチル化は BF $_{9}-$

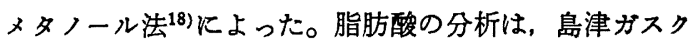
ロマトグラム, モデル GC-4 APF を使用し, カラム充 填剤は diethylene glycol succinate 15\% (shimalite 201)メッシュ80〜100 を用いた。カラムの温度は 195 ${ }^{\circ} \mathrm{C}$ 。キャリアーガスは $\mathrm{N}_{2}$ 。流速は $60 \mathrm{ml} / \mathrm{min}$ 。脂肪酸 の定量は半値幅法によった。

\section{6. 病理組蟣学的検索}

飼育 10 および 20 週後の腎, 心, 肝, 脳および大動 脈のへマトキシリン・エオジン染色，マッリン・エラス チカ染色を行なった。

\section{実 験 結 果}

\section{1. 体重および血圧}

体重は実験開始直後, I 群を除き当初減少したが, 2 3 週で回復した。10 週以降は, バーを与えた II, N 群 で有意に高かった。各群の実験屠殺時体重を Fig. 1 に 示した。血圧は 2 週に 1 度測定したが，各群終始 100〜 $125 \mathrm{mmHg}$ で有意差はなかった。

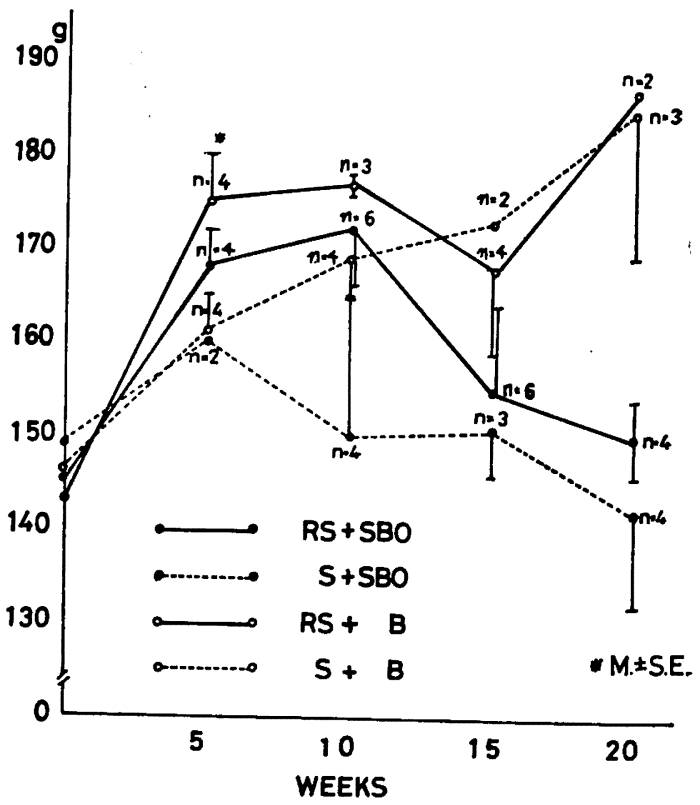

Fig.1. Body weights (g) of the experimental rats. 


\section{2. 血清脂留}

血清中性脂肪值の飼育期間による变化を, Fig. 2 飞示 した。群を除き，10,15 週で低下し，20 週で增加して いる。脂質として大豆油を与えだズミでは，米でん粉 群に比し蔴糖群は高値を示し $(P<0.05)$, バターを与兄 たネズミでは，10，15 週で逆に米でん粉群に比し蔗糖 群が低値を示したが $(P<0.05)$ ，大豆油，バター群とも 20 週では糖質の種類による差はなかった。脂質の差に 着目してみると，米でん粉群ではバターを与えた方が有 意保高 $<(5$ 週 $P<0.05,10,15$ 週 $P<0.01,20$ 週 $P<0.20)$, 蔗桾群もバターを与えた方が高い傾向にはあ るが, 推計学的には 10 週で有意差を認めただけであっ た $(P<0.01)$ 。

血清コレステロール值の時間的推移を Fig. 3 に示した。 大豆油群は米でん粉を蔗糖におきかえても，血清中性脂 肪值に見られたような著明な差は見られなかった。バタ 一を与えたネズミでは，蔗桾群は米でん粉群に比し 5 週 目に高値を示したが $(P<0.01) ， 15 ， 20$ 週ではむしろ逆 に低值を示した。脂質による差は，米でん粉群では有意 差はなく, 蕉糖群は 15 週までバター群が高く $(P<0.01)$, 20 週では差はなかった。

飼育期間による血清リン脂質の推移を Fig.4 に示した。 大豆油群では蓔糖を与えた方が米でん粉を与えたものよ ク，5，10 週で高い傾向にあったが，15 週以降はむしろ

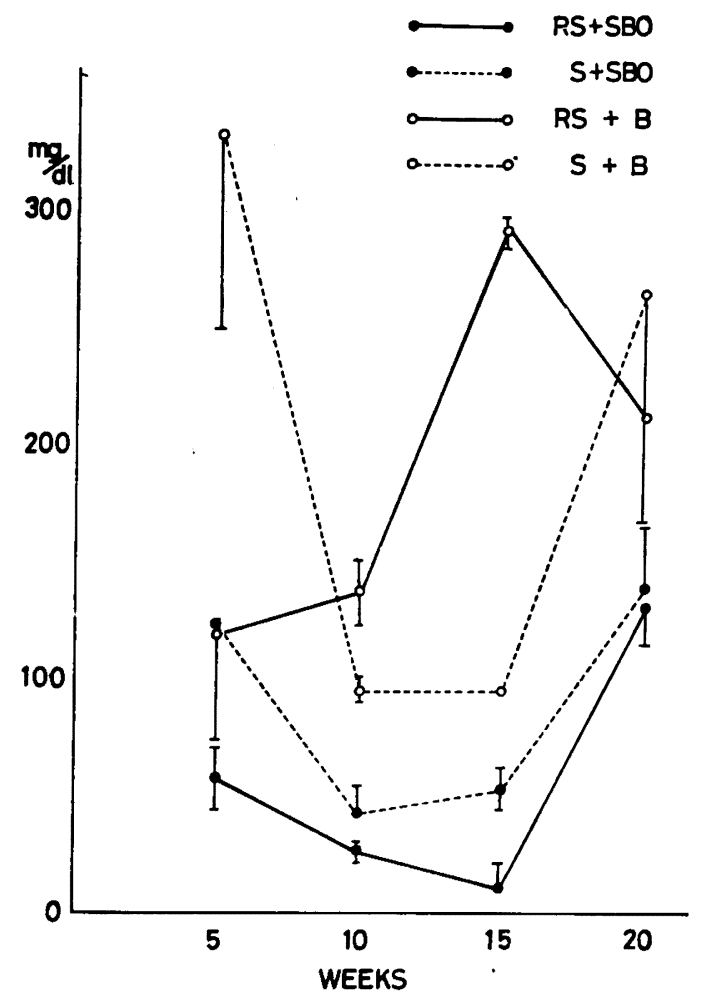

Fig. 2. Serum triglyceride.
逆であった。バターを与えた群は糖質の差による变化は 著明でなかった。脂質の差についてみると米でん粉群， 莽糖群ともバターを与えた方で高かったが $(P<0.01$,

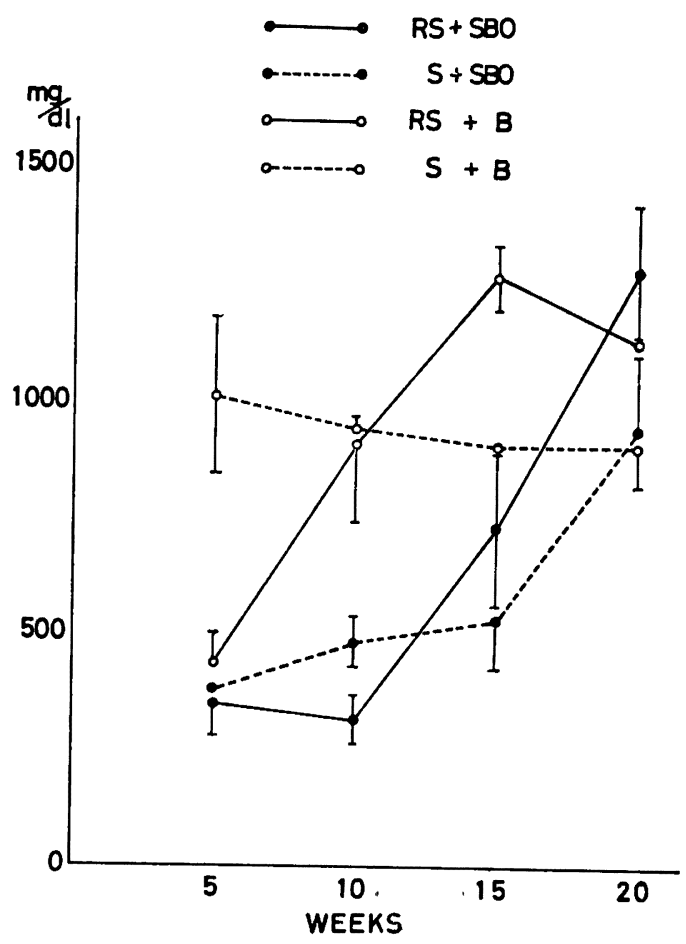

Fig. 3. Serum cholesterol.

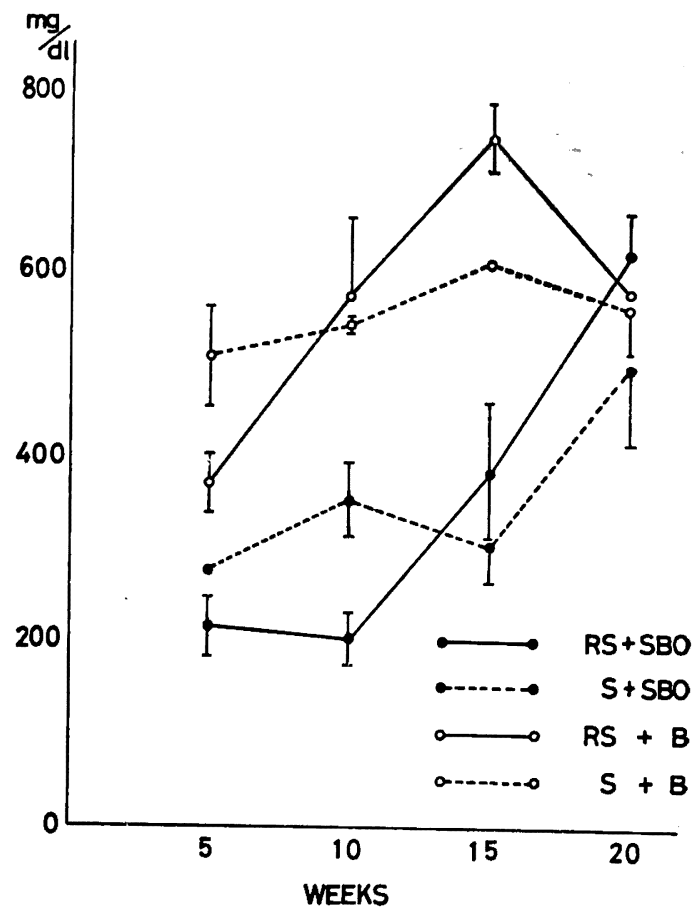

Fig.4. Serum phospholipid. 
$P<0.05) 20$ 週では差はなかった。

3. 肝 脂 澌

肝重量 (g/100 g body weight) は 15 週までは有意 差はなく，各群飼育期間とともに上昇したが，20 週で

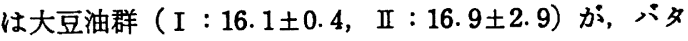

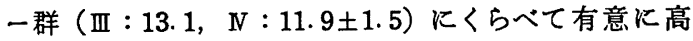
かった $(P<0.01, P<0.05)$ 。

肝総脂質, コレステロールの值を Fig. 5 に示した。両
者とも，20 週のバターを与えたネズミで，蒸糖群の方 が米でん粉群よりす高値を示したが，その他糖の種類に よる差はなかった。食䬲脂質による差を比較すると，米 でん粉，蔴桾群ともに大豆油群で有意に高く、これは血 清での傾向とくらべてむしろ逆であった。

4. 血清脂酸構成比

血清の脂酸構成比を Table 2 に示した。各群の飼育期 間の変化をみると I, II 群ではパルミチン酸の上昇，才

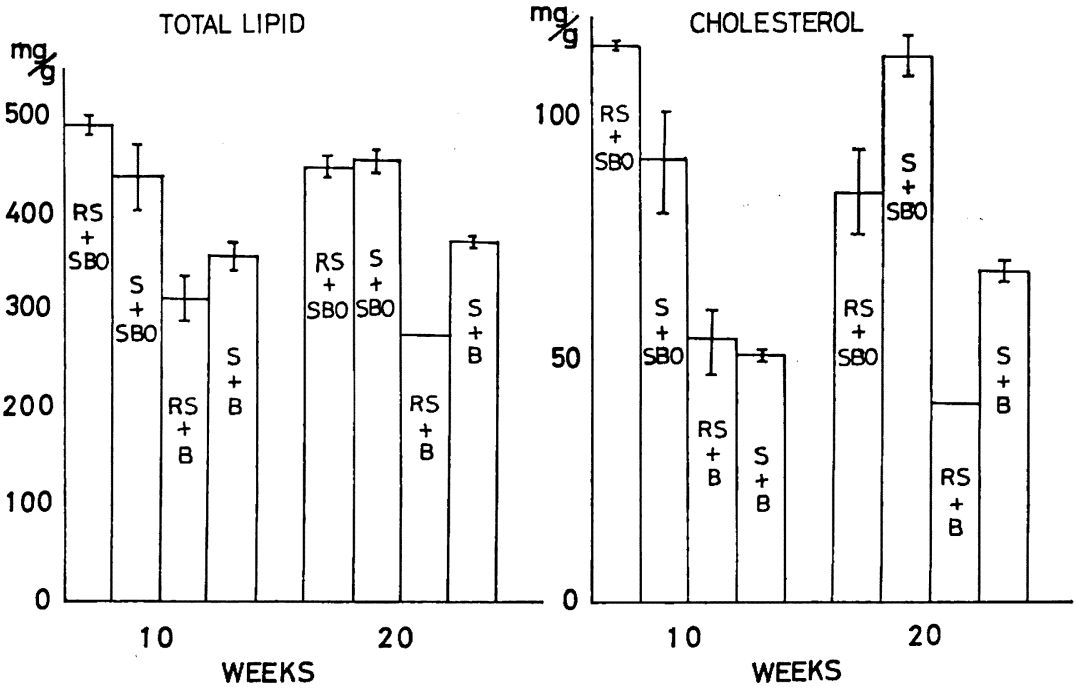

Fig. 5. Total lipid and cholesterol in liver.

Table 2. Serum fatty acid composition. (\%)

\begin{tabular}{|c|c|c|c|c|c|c|c|c|c|c|}
\hline \multicolumn{2}{|c|}{ Froups } & $\mathrm{C}_{14}$ & $\mathrm{C}_{16}$ & $C_{16: 1}$ & $\mathrm{C}_{18}$ & $C_{18: 1}$ & $C_{18: 2}$ & $\mathrm{C}_{20: 3}$ & $\mathrm{C}_{20: 4}$ & $\mathrm{~L} / \mathrm{O}_{\text {ratio }}$ \\
\hline \multirow{4}{*}{ weeks } & I & $\mathrm{t}$ & 16. $0 \pm 0.7^{* *}$ & $1.9 \pm 0.6$ & $13.2 \pm 1.6$ & $17.7 \pm 1.0$ & $39.6 \pm 3.3$ & $2.5 \pm 0.6$ & 9. $0 \pm 3.1$ & $2.2 \pm 0.2$ \\
\hline & III & $0.6 *$ & 15.1 & 1. 2 & 12.6 & 19.8 & 44.6 & 1.8 & 4. 6 & 2.3 \\
\hline & III & $1.2 \pm 0.4$ & $22.0 \pm 2.2$ & $3.8 \pm 1.2$ & $11.5 \pm 3.5$ & $23.3 \pm 3.0$ & $33.5 \pm 6.2$ & $0.6 \pm 0.7$ & 4. $2 \pm 1.5$ & $1.5 \pm 0.4$ \\
\hline & N & 3. $1 \pm 1.7$ & $28.8 \pm 2.3$ & $10.0 \pm 2.4$ & 11. $6 \pm 1.6$ & $34.3 \pm 2.4$ & $9.6 \pm 1.3$ & $\mathrm{t}$ & $2.7 \pm 0.9$ & $0.3 \pm 0.1$ \\
\hline \multirow[b]{2}{*}{10} & I & $\mathrm{t}$ & $17.7 \pm 1.1$ & $2.0 \pm 0.6$ & $17.5 \pm 1.3$ & 16. $1 \pm 1.3$ & $35.8 \pm 1.9$ & $0.9 \pm 0.6$ & 10. $0 \pm 1.0$ & $2.2 \pm 0.2$ \\
\hline & II & $\mathrm{t}$ & $18.6 \pm 1.5$ & $1.7 \pm 0.3$ & $16.4 \pm 1.5$ & $16.1 \pm 2.1$ & $38.3 \pm 1.3$ & 1. $2 \pm 1.0$ & $7.8 \pm 0.5$ & $2.4 \pm 0.1$ \\
\hline \multirow[t]{3}{*}{ weeks } & III & $1.5 \pm 0.5$ & $28.2 \pm 1.6$ & $5.4 \pm 0.7$ & $13.9 \pm 0.9$ & $34.6 \pm 0.5$ & $12.7 \pm 2.8$ & $\mathbf{t}$ & $3.7 \pm 0.7$ & $0.4 \pm 0.1$ \\
\hline & $\mathrm{N}$ & $1.6 \pm 0.1$ & $25.6 \pm 1.2$ & $10.2 \pm 0.6$ & $11.6 \pm 1.1$ & $36.2 \pm 1.5$ & $10.3 \pm 0.5$ & $\mathrm{t}$ & $4.5 \pm 0.5$ & $0.3 \pm 0.02$ \\
\hline & I & $0.2 \pm 0.1$ & $19.9 \pm 1.2$ & $2.0 \pm 0.7$ & $15.1 \pm 1.6$ & $15.4 \pm 1.8$ & $36.6 \pm 1.2$ & $0.7 \pm 0.6$ & $10.0 \pm 2.0$ & $2.4 \pm 0.2$ \\
\hline 15 & II & $0.2 \pm 0.1$ & $18.6 \pm 0.4$ & $2.1 \pm 0.4$ & $16.6 \pm 1.0$ & $16.6 \pm 1.0$ & $35.3 \pm 1.6$ & $1.4 \pm 0.3$ & $9.4 \pm 2.1$ & $2.1 \pm 0.1$ \\
\hline \multirow{3}{*}{ weeks } & III & $2.2 \pm 0.2$ & 28. $0 \pm 1.6$ & $6.7 \pm 1.2$ & $12.5 \pm 1.1$ & $33.8 \pm 3.1$ & $13.3 \pm 3.0$ & $t$ & $3.6 \pm 0.9$ & $0.4 \pm 0.1$ \\
\hline & $\mathrm{N}$ & 1. $4^{*}$ & 30.4 & 6.5 & 11.7 & 36.2 & 9.8 & $\mathrm{t}$ & 4.2 & 0.3 \\
\hline & I & $0.5 \pm 0.5$ & $19.9 \pm 0.6$ & $2.2 \pm 0.6$ & $15.2 \pm 2.1$ & $15.2 \pm 0.7$ & $37.2 \pm 1.2$ & $1.4 \pm 0.2$ & $8.4 \pm 0.7$ & $2.5 \pm 0.2$ \\
\hline \multirow{3}{*}{$\begin{array}{c}20 \\
\text { weeks }\end{array}$} & II & $0.3 \pm 0.3$ & $19.5 \pm 0.6$ & $1.8 \pm 0.3$ & $15.5 \pm 2.1$ & $16.7 \pm 0.3$ & $36.0 \pm 1.0$ & $1.3 \pm 0.3$ & $9.1 \pm 1.1$ & $2.2 \pm 0.04$ \\
\hline & III & 2. $3^{*}$ & 28.2 & 7.7 & 11.5 & 35.8 & 10.2 & t & 4. 4 & 0.3 \\
\hline & N & $2.7 \pm 1.9$ & $31.5 \pm 3.6$ & $8.4 \pm 0.7$ & $11.0 \pm 1.8$ & $35.4 \pm 2.2$ & $7.2 \pm 0.8$ & $\mathrm{t}$ & $3.8 \pm 0.9$ & $0.2 \pm 0.01$ \\
\hline
\end{tabular}

$\mathrm{t}=$ trace

* mean of two rats

** standard division of mean 
レイン酸の低下がみられ，正群ではパルミチン酸, パル ミトオレイン酸, オレイン酸の上㫒, リノール醊の低下 がみられた。また $\mathrm{N}$ 群ではアラキドン酸の上昇，パルミ チン酸、リノール酸の低下が見られた。糖質の差による 変化は，飼育期間を通して著明ではなかった。大豆油群 はパタ一群にくらべて, パルミチン酸, パルミトオンイン 酸、オンイン酸の減少, ステアリン酸, リノール酸, ア ラキドン酸の增加がみられた。一般に動脈硬化症の指標 の一つとされているリノール酸とオンイン酸の比,すな わち L/O 比についてみるといずれる大豆油, ハィーの L/0 比，2.72，0.19 を反映していたが， 5 週の III群は正 常値に近く，蔗糖と米でん粉の差がみられた。その他の 糖質による差はなかった。

\section{5. 病理組織学的検索}

10 週の肝荗において, 線維化の程度が大豆油群で軽 度であったが, その他, 大動脈, 臓器内血管において, 著明な動脈硬化病変はみられなかった。

\section{考察}

高脂肪食の際の糖質と脂質の組合せによる影響を，主 として血清および訮脂質の面から検討した。血清脂質 は, 与えた脂質に着目すると，バタ一群は大豆油群にく らぺて高い傾向にあり従来の研究と一致7) 10)19)した。し かし，飼育期間が 20 週といら長期になるとその差はま ったく認められなかったが，これは各群とも肝機能障害 が高度になるためと考えられた。

一方，糖質について蔗糖とでん粉を比較すると，血清 脂質は䓞糖群で高い値を示すと一般にはいわれている が(1) 3), 他方グルコース, 蔗糖, でん粉, 水解でん粉を 比較して，でん粉群が最も atherogenic であるという報 告20) ある。本実験では組み合わされる脂質，および飼 育期間によって米でん粉群と蔗糖群は逆の傾向を示する のるあり (中性脂肪でより著明), Carroll12)19) が行なっ た実験結果に示されているように，炭水化物一脂質の interrelationship の複雑珄を示しているすのと思われ る。肝脂質において,糖質による差は見られなかったが， Balley21) らはラットにおいて hepatic lipogenesis はフ ラクトース群がグルコース群にくらべて大きいと述べて いる。これらの差は，使用した糖質や脂質の違い，量的 な差, コレステロール添加の有無、飼育期間の違いなど によるるのと思われる。

次に血清脂酸構成についてみると，脂質の依存度が大 きく，糖質による差は飼育 5 週の III群(䓞糖十大豆油群) でみられたたけであったが，五島ら 22 は，犬においてフ ラクトースとグルコースについて比較検討し，フラクト 一ス投与犬の肝中性脂肪分画のパルミチン酸, オレイン 酸の増加とリノール酸の減少を認めている。本実験です
5 週目のバター投与群において, 蔗糖群は米でん粉群に くらぺて, パルミチン酸, オレイン酸の増加, リノール 酸、アラキドン酸の減少を認めこれら減少した脂酸が体 内で合成不可能なるのであることを考えると興味深い。 田中到はヒトに拈いて，動脈硬化患者ではリノール酸の 比率が低く、すなわちリノール酸とオレイン酸の比が 1.0 以下になるのをみているが，本実験では食慨中の大豆油 とバターのそれに依存しており，此較はできなかった。

病理学的には, 肝硬変の程度に差があった他は, 動脈 硬化の初期像といわれている著明な内膜肥厚はみられな かった。腎缄の細動脈に内膜の肥厚とみられる変化がみ られたものもあったが有意差はなく，明らかな動脈硬化 病変は認められなかった。高脂肪, コレステロール， チ オウラシル, コール酸添加食で 20 週間飼育した本実験 においても著明な変化は見られず，ラットは，食餌性コ レステロールに対する耐性が強く，実験的動脈硬化症を つくりにくいといら先人の報告を裏書きする結果となっ たが，ラットに動脈硬化症を作製できたと報告してい るGresham ${ }^{11)}$ らの方法より脂質の割合が少ないことに 原因しているかるしれない。

ラットでの結果をヒトにそのままあてはめることはで きないが，以上のことから，脂質代謝に対する食餌性脂 質の影響を考えるときに，同時に食餌中の糖質の種類を 考虑する必要があり，とくに食飰中の脂質と糖質の組合 せは, 複雑な問題を内臓しているるのと思われる。

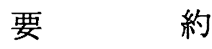

動脈硬化と食餌因子との関連については多くの研究が あるが，その中で糖質の影響を考える場合，たんに糖質 の質のみでなくこれに組み合わされる脂質の種類が重要 であると考えて，以下の組合せにより高脂肪食の際の糖 質の影響を脂質代謝の面から検討した。

体重 $150 \mathrm{~g}$ 前後のウイスター系白ネズミ雄に, 次の 4 種類の食餌を与え 20 週間飼育した。カゼイン 20 , 糖質

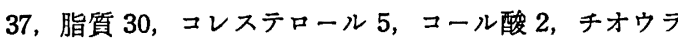
シル 0.3, 塩混合 4, ビタミン混合 1.5 , 塩化コリン 0.2 , 糖質と脂質の組合せは, 米でん粉十大豆油, 蔗糖十 大豆油, 米でん粉十バタ一, 蔴糖十バターの 4 群とし, $5,10 ， 15 ， 20$ 週目に屠殺，血液拈よび肝の脂質分析と 腎, 心, 肝, 脳, 大動脈の組織学的検索を行なった。 血清の中性脂肪は，大豆油群では米でん粉を与えたる のより䓞糖を与えた方が高く，バタ一群では逆だった。

血清コレステロールは, 大豆油群では米でん粉, 蔗糖 の間に著明な差はなく，バター群では 5 週目に庶糖群が 米でん粉群より高かったが長期飼育では逆であった。

血清リン脂質は, 大豆油, バター群とも初期には米で ん粉群より蔗糖群で高かったが長期では差はなかった。 
肝総脂質、コレステロールは，糖質による著明な差は なく，バター群で低く，血清での傾向と必ずしも一致し なかった。

終りにこの研究にご助言いただきました古徳利光博 士, 病理組織学的検索にご指導,ご助力いただきました 深沢傅士，白沢 満氏，動物飼育にご協力いただきま した佐藤了说氏に感謝します。

本研究の要旨は, 昭和 46 年 11 月, 第 13 回日本老年 医学会総会で報告した。

\section{文献}

1) Joseph, T. A. : Am. J. Clin. Nutr., 20, 168 (1967)

2) Nutr. Rev. : 23, 183 (1965)

3) ibid.: 23, 292 (1965)

4) Yudkin, J. : Lancet, 2, 4 (1964)

5) Yudkin, J. : ibid., 2, 6 (1964)

6) Yudkin, J. et al. : Am. J. Clin. Nutr., 20, 503 (1967)

7) Ahrens, E. H. et al. : Lancet, 1, 943 (1957)
8) Ahrens, E. H. et al. : J. Clin. Invest., 34, 918 (1955)

9) Kinsell, L. W. et al. : Am. J. Clin. Nutr., 3, 247 (1955)

10) Beveridge, J. M. R. et al. : Canad. J. Biochem., 34, 441 (1956)

11) Gresham, G. A. et al. : Brit. J. Exp. Path., 42, 166 (1961)

12) Carroll, C. : J. Nutr., 79, 93 (1963)

13) Carroll, C. : ibid., 82, 163 (1964)

14) 二国二郎：澱粉の化学, p. 512，(1951）朝倉書店

15）曾我部博丈 : 実験高血圧症入門, p. 199 (1968), 英光堂書店

16) Folch, J. et al. : J. Biol. Chem., 226, 497 (1957)

17) Folch, J. : ibid., 191, 833 (1951)

18) Metcarfe, L.D. : Anal. Chem., 39, 514 (1966)

19) Yamamoto, I. et al.: Atheroscler., 13, 171 (1971)

20) Kritchevsky, D. et al. : J. Atheroscler. Res., 8, 697 (1968)

21) Balley, E. et al. : Nature, 217, 471 (1968)

22）五島雄一郎ら：日老医誌，3，295 (1966)

23）田中 圭：日内誌, 50, 790 (1967)

(昭和 47 年 6 月 20 日受理) 